\title{
Karakteristik Buah Dan Biji Terong (Solanum Melongena .L var. Kenari) Setelah Diberi Ekstrak Air Akar Eceng Gondok (Eichhornia crassipes)
}

\author{
Fida Alvitasari ${ }^{1}$, Tatang Sopandi ${ }^{2}$ \\ ${ }^{1}$ Mahasiswa Prodi Biologi FMIPA Universitas PGRI Adi Buana Surabaya \\ ${ }^{2}$ Staf Pengajar Prodi Biologi FMIPA Universitas PGRI Adi Buana Surabaya \\ Email : fidaalvita@gmail.com ${ }^{1}$
}

\begin{abstract}
Thai aubergine or eggplant, or goes by local name terong kenari (Solanum melongena L. var Kenari), is a vegetable included in the family Solanaceae. Eggplant loved by most of Indonesians, either eaten fresh or cooked. However, some often despise eggplant's seeds as it may cause digestive problem. Plant hormone in controlling plants' growth, such as giberelin, are frequently used to produce seedless or no-seed eggplant. This study is conducted to test the impact of water hyacinth, or goes by local name eceng gondok (Eichhornia crassipes), root extract treatment in the characteristic of eggplant (Solanum melongena L. var Kenari) fruit and seeds. This research is done in experimental manner, using the completely randomized design, including four different extract's concentration; $0 \mathrm{~g} / \mathrm{L}, 50 \mathrm{~g} / \mathrm{L}, 100 \mathrm{~g} / \mathrm{L}$, and $150 \mathrm{~g} / \mathrm{L}$; and one giberelin treatment that are given five times, repeatedly. According to the research conducted, the water hyacinth root extract treatment results in the increase of the quantity and weight of the eggplant, and also the reduction in seeds, as it also affects the fruit skin layer thickness. As in the study, the optimum outcome is obtained with the concentration of $150 \mathrm{~g} / \mathrm{L}$ water hyacinth root extract; which result in average number of fruit 6.6 for each plant, average weight 179.57 gram per fruit, average number of seeds 561 per fruit, average weight 6.14 gram per seed, and average skin thickness 0.78 in each eggplant.
\end{abstract}

Keywords: Eggplant, gibberellin hormone, water hyacinth, characteristic of eggplant fruit and seeds

\section{PENDAHULUAN}

Terong (Solanum melongena .L) merupakan tanaman sayur-sayuran yang termasuk famili Solanaceae. Buah terong disenangi sebagian besar orang indonesia, baik sebagai lalapan segar maupun diolah menjadi berbagai jenis masakan. Permintaan terhadap terong terus meningkat sejalan dengan pertambahan penduduk yang diikuti meningkatnya kesadaran akan manfaat sayur-sayuran dalam memenuhi gizi keluarga, sehingga produksi terong perlu ditingkatkan (Jumini, et al., 2009). Hal tersebut sesuai dengan data Kementrian Pertanian Republik Indonesia (2017), dimana produksi terong pada tahun 2013-2014 mencapai 557,040 ton.

Buah tanpa biji juga dapat meningkatkan kualitas buah ketika buah tersebut memiliki biji keras atau memiliki rasa yang buruk (Pandolfini, 2009).Auksin, giberelin dan sitokinin atau campuran dari hormon-hormon tersebut dilporkan terbukti efektif mendorong perkembangan buah tanpa pemupukan pada beberapa spesies tanaman, misalnya tomat dan terong (Gillaspy et al., 1993).Giberelin (GAs) merupakan kelompok fitohormon yang berperan penting dalam mengkoordinasikan pertumbuhan buah dan pengembangan benih (Pandofilni, 2009).

Penghambatan pembentukan biji dengan partenokarpi pada buah biasanya dilakukan dengan cara mengaplikasi zat pengatur tumbuh, seperti giberelin pada bunga tanaman (Purnamaningsih et al., 2010). Penggunaan giberelin banyak dilakukan oleh produsen anggur tanpa biji (Suwanto, 2002). Perlakuan giberelin ini mengakibatkan tidak terbentuknya biji karena gangguan pertumbuhan tabung sari sebelum pembuahan (Suwanto, 2002). Aplikasi hormon giberelin tebukti berpengaruh terhadap pembentukan buah tanpa biji pada semangka (Annisah, 2009). Selanjutnya Annisah (2009) mengemukakan bahwa pemberian hormon giberelin berpengaruh terhadap jumlah biji, ukuran dan bobot buah. Namun demikian, hormon giberelin yang banyak digunakan untuk menurunkan jumlah biji atau menghasilkan buah tanpa biji 
umumnya menggunakan hormon giberelin sintetis yang mahal dan ketersediaannya terbatas. Oleh karena itu perlu dicari sumber hormon giberelin dari bahan alam sebagai pengganti hormon giberelin sintesis.

Zat Pengatur Tumbuh (ZPT) mutlak dibutuhkan tanaman, Karena tanpa ZPT tidak akan terjadi pertumbuhan walaupun unsur hara memadai (Wareing dan Phillps, 2001). Salisbury dan Ross (2005) menyatakan bahwa, konsep ZPT diawali dengan konsep hormon yaitu senyawa organik tanaman yang dalam konsentrasi rendah akan mempengaruhi proses fisiologis terutama diferensiasi dan perkembangan tanaman.

Giberelin merupakan hormon sintetik bagi pertumbuhan yang berpengaruh terhadap pertumbuhan tanaman, dari perkecambahan sampai senesen dan yang terpenting pada pembelahan sel dan pembesaran sel (Chudasama dan Thaker, 2007). Menurut Natesh, et al., (2005) pemberian hormon giberalin (GA3) pada tahap pembungaan dapat meningkatkan pertumbuhan dan jumlah biji terong. Penyemprotan giberalin $100 \mathrm{ppm}$ meningkatkan jumlah buah dan biji terong dibandingkan dengan $50 \mathrm{ppm}$. Hormon giberelin sintetik cukup mahal dan ketersediaannya terbatas, sehingga digunakan alternatif pengganti yaitu hormon giberelin alami yang berasal dari akar eceng gondok.

Eceng gondok (Eichhornia Crassipes) merupakan tanaman air yang mengapung yang memiliki bunga yang menarik. Tanaman ini memiliki kemampuan untuk beradaptasi dari perubahan kecepatan air yang ekstrim, perubahan kadar nutrisi, $\mathrm{pH}$ (derajat keasaman tanah), temperatur dan ketinggian air (Anonim, 2011). Eceng gondok merupakan tanaman air yang dianggap gulma di lingkungan perairan karena penyebarannya sangat cepat dan tidak terkendali yang dapat menimbulkan banyak kerugian yakni mengurangi produktivitas lahan air yakni mengambil ruang, mengambil unsur hara yang juga dibutuhkan oleh ikan (Wardini, 2008). Namun demikian, enceng gondok diketahui mempunyai kandungan protein yang cukup tinggi yaitu antara 12-18\% serta kandungan asam amino cukup lengkap yang dapat dimanfaatkan sebagai pengganti hormon giberelin (Bayyinatul, et al., 2012). Akar eceng gondok (Eichhornia crassipes) diketahui mengandung hormon giberelin (Musbakri, 1999). Menurut Ferdia Windarti dan Tatang Sopandi (2018) melaporkan bahwa, penggunaan ekstrak akar eceng gondok pada konsentrasi $75 \mathrm{~g} / \mathrm{L}$ berpengaruh tehadap hasil panen baik jumlah dan berat buah cabai rawit serta terbukti dapat menurunkan jumlah biji per buah cabai rawit. Penelitian mengenai pemanfaatan ekstrak akar eceng gondok sebagai pengganti hormon giberelin untuk karakteristik buah dan biji terong yang belum pernah dipublikasikan. Penelitian ini bertujuan untuk mengeksplorasi efek pemberian ekstrak akar eceng gondok terhadap jumlah dan berat buah, jumlah dan berat biji, tebal kulit buah terong.

\section{METODE PENELITIAN}

Penelitian ini telah dilaksanakan secara eksperimental pada bulan Februari sampai Juni 2019 di Badan Penyuluh Pertanian Dinas Pangan Dan Pertanian Kabupaten Sidoarjo, Kecamatan PorongKabupaten Sidoarjomenggunakanmetode rancangan acak lengkap (RAL) terdiri atas 5 perlakuan pemberian konsentrasi sari akar eceng gondok yaitu $0,50,100,150$ $\mathrm{g} / \mathrm{l}$, dan hormon giberelin yang masingmasing diulang $5 \mathrm{kali}$.

\section{Pembuatan sari akar eceng gondok}

Pembuatan sari akar eceng gondok dilakukan dengan cara memilih akar eceng gondok yang masih segar dan tidak busuk. Akar eceng gondok dicuci hingga bersih. Akar eceng gondok ditimbang dan dibagi masing-masing dengan berat $250 \mathrm{~g}$, 
$500 \mathrm{~g}$, dan 750 g. Masing-masing akar eceng gondok tersebut dicampurkan dalam aquades sebanyak $1,5 \quad 1$ dan dilumatkan, sehingga diperoleh konsentrasi 25, 50, dan 75 g/l. Campuran diaduk homogen, dibiarkan selama 2 menit, disaring dan diperas untuk memperoleh ekstrak akar eceng gondok.

\section{Aplikasi pada tanaman}

Sebanyak 25 batang bibit cabai rawit yang berumur 30 hari ditanam secara individu dalam polybag dengan media tanah dan pupuk organik dibagi 5 kelompok masing-masing 5 tanaman. Setiap kelompok disemprot ekstrak akar eceng gondok dengan konsentrasi 0, 50, $100,150 \mathrm{~g} / \mathrm{l}$, dan hormon giberelin. Perlakuan dengan pemberian ekstrak akar eceng gondok tiap tiga hari sekali dengan disemprot setiap pagi hari sampai tanaman terong berbuah.

\section{Analisis statistika}

Semua data hasil pengamatan dianalisis statistika menggunakan analisis varian satu arah pada taraf signifikansi 0,05 . Uji lanjut untuk mengetahui letak perbedaan antar perlakuan dilakukan dengan menggunakan Uji BNT (Beda Nyata Terkecil) dengan taraf signifikansi 0,05 .

\section{HASIL DAN PEMBAHASAN \\ Jumlah dan Berat Buah Tanaman Terong \\ Jumlah Buah Terong}

Hasil penelitian perlakuan pemberian ekstrak akar eceng gondok terhadap jumlah buah terong disajikan pada gambar 5.1. Hasil penelitian memperlihatkan bahwa pemberian ekstrak akar eceng gondok berpengaruh signifikan $(\mathrm{P}<0.05)$ terhadap jumlah buah terong. Jumlah buah terong pada tanaman yang diberi perlakuan $0 \mathrm{~g} / \mathrm{L}$ sebagai kontrol negatif yaitu (3.2 \pm 0.04 buah) signifikan $(\mathrm{P}<0.05)$ lebih rendah dibandingkan dengan perlakuan ekstrak akar eceng gondok $50 \mathrm{~g} / \mathrm{L}$ (4.6 \pm 0.05 buah), $100 \mathrm{~g} / \mathrm{L}$ (5.6 \pm 0.05 buah), $150 \mathrm{~g} / \mathrm{L}$ (6.6 \pm 0.05 buah), dan pemberian hormon giberelin sebagai kontrol positif (7.6 \pm 0.05 buah). Jumlah buah pada tanaman yang diberi perlakuan $50 \mathrm{~g} / \mathrm{L}(4.6 \pm 0.05$ buah)signifikan $(\mathrm{P}<0.05)$ lebih rendah dibandingkan dengan perlakuan ekstrak akar eceng gondok 100 $\mathrm{g} / \mathrm{L}$ (5.6 \pm 0.05 buah) dan perlakuan ekstrak akar eceng gondok $150 \mathrm{~g} / \mathrm{L} \quad(6.6 \pm 0.05$ buah). Perlakuan ekstrak akar eceng gondok $100 \mathrm{~g} / \mathrm{L}(5.6 \pm 0.05$ buah)signifikan $(\mathrm{P}<0.05)$ lebih tinggi dibandingkan dengan perlakuan ekstrak akar eceng gondok $150 \mathrm{~g} / \mathrm{L} \quad(6.6 \pm 0.05$ buah $)$. Jumlahbuah terong tertinggi diperoleh pada perlakuan ekstrak akar eceng gondok $150 \mathrm{~g} / \mathrm{L}$.

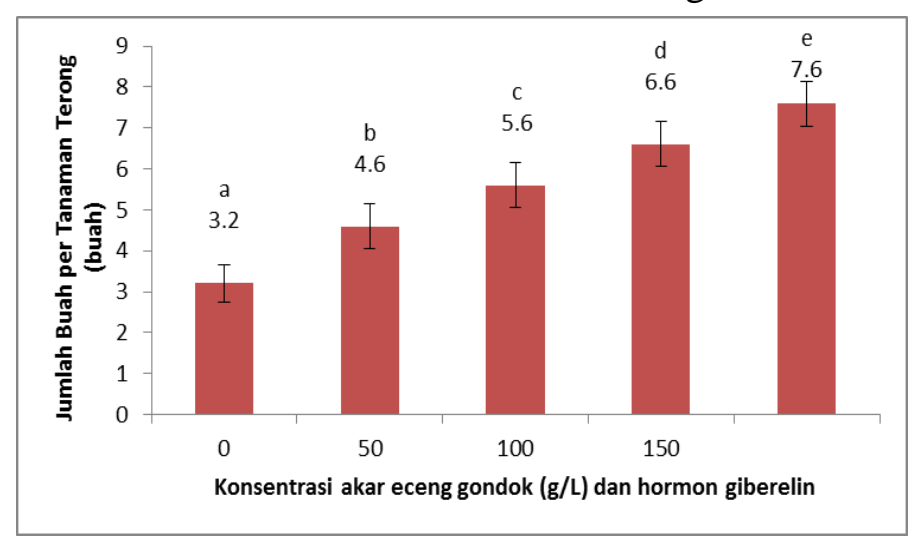

Gambar 5.1 Jumlah buah terong (Solanum melongena .L) setelah diberi perlakuan ekstrak akar eceng gondok dan hormon giberelin 
Setiap pemberian ekstrak akar eceng gondok berpengaruh signifikan $(\mathrm{P}<0.05)$ terhadap jumlah buah terong (Solanum melongena .L). Pemberian ekstrak eceng gondok pada konsentrasi D memiliki hasil tertinggi, yaitu dengan ratarata 6.6 buah. Perlakuan A berbeda nyata dengan perlakuan dengan konsentrasi A,B,C,dan D. Sedangkan perlakuan B berbeda nyata dengan perlakuan $\mathrm{C}$ dan $\mathrm{D}$. Perlakuan $\mathrm{C}$ berbeda nyata dengan perlakuan D. Pada pemberian hormon giberelin (E) memiliki jumlah buah lebih tinggi dibandingkan dengan pemberian ekstrak akar eceng gondok dengan konsentrasi D.

\section{Berat Buah}

Hasil penelitian perlakuan pemberian ekstrak akar eceng gondok terhadap berat buah terong disajikan pada gambar 5.2. Hasil penelitian ini memperlihatkan bahwa pemberian ekstrak akar eceng gondok berpengaruh signifikan $(\mathrm{P}<0.05)$ terhadap berat buah terong. Berat buah terong pada tanaman yang diberi perlakuan $0 \mathrm{~g} / \mathrm{L}$ sebagai kontrol negatif $(107.72 \pm 14.5 \quad$ g) signifikan $(\mathrm{P}<0.05)$ lebih rendah dibandingkan dengan perlakuan ekstrak akar eceng gondok $50 \mathrm{~g} / \mathrm{L}(132.28 \pm 16.9 \mathrm{~g}), 100 \mathrm{~g} / \mathrm{L}$ $(155.18 \pm 14.6 \mathrm{~g}), 150 \mathrm{~g} / \mathrm{L}(179.57 \pm 12.2$ g), dan pemberian hormon giberelin sebagai kontrol positif $(206.95 \pm 15.1 \mathrm{~g})$. Perlakuan ekstrak akar eceng gondok 50 $\mathrm{g} / \mathrm{L}(132.28 \pm 16.9 \mathrm{~g})$ signifikan $(\mathrm{P}<0.05)$ lebih rendah dibandingkan dengan perlakuan ekstrak akar eceng gondok 100 $\mathrm{g} / \mathrm{L} \quad(155.18 \pm 14.6 \quad \mathrm{~g})$ dan perlakuan ekstrak akar eceng gondok $150 \mathrm{~g} / \mathrm{L}$ (179.57 \pm 12.2 g). Perlakuan ekstrak akar eceng gondok $100 \mathrm{~g} / \mathrm{L} \quad(155.18 \pm 14.6$ g)signifikan $\quad(\mathrm{P}<0.05) \quad$ lebih rendah dibandingkan dengan perlakuan ekstrak akar eceng gondok $150 \mathrm{~g} / \mathrm{L}(179.57 \pm 12.2$ g). Berat buah terong tertinggi diperoleh pada perlakuan ekstrak akar eceng gondok $150 \mathrm{~g} / \mathrm{L}$. Pemberian hormon giberelin sebagai kontrol positif memiliki berat buah terong lebih tinggi dibandingkan dengan pemberian ekstrak akar eceng gondok dengan konsentrasi $150 \mathrm{~g} / \mathrm{L}$.

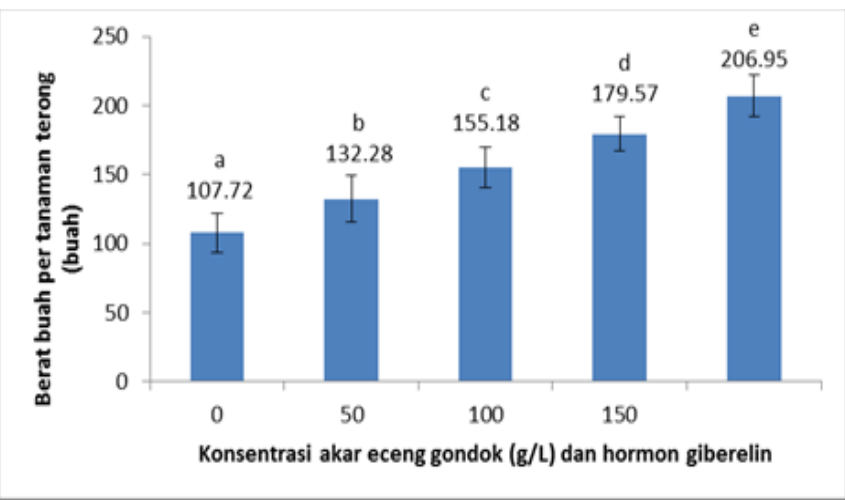

Gambar 5.2 Berat buah terong (Solanum melongena.L) setelah diberi perlakuan ekstrak akar eceng gondok dan hormon giberelin

Setiap pemberian ekstrak akar eceng gondok berpengaruh signifikan $(\mathrm{P}<0.05)$ terhadap berat buah terong (Solanum melongena .L). Pemberian ekstrak eceng gondok pada konsentrasi $150 \mathrm{~g} / \mathrm{L}$ memiliki hasil tertinggi, yaitu dengan rata-rata $179.57 \mathrm{~g}$. Perlakuan A berbeda nyata dengan perlakuan dengan konsentrasi A,B,C, dan D. Sedangkan perlakuan $\mathrm{B}$ berbeda nyata dengan perlakuan $\mathrm{C}$ dan D. Perlakuan $\mathrm{C}$ berbeda nyata dengan perlakuan D. Pada pemberian hormon giberelin (E) memiliki berat buah lebih tinggi dibandingkan dengan pemberian ekstrak akar eceng gondok dengan konsentrasi D.

Menurut Wardini (2008), dalam tumbuhan eceng gondok terdapat hormon 
yang bekerja secara aktif dalam dinding sel sehingga dapat mempercepat pertumbuhan batang, daun dan sistem perakaran. Kandungan eceng gondok memiliki nitrogen yang cukup sehingga dapat meningkatkan sintesis protein untuk pembelahan dan pembesaran sel. Giberelin dapat berpengaruh terhadap pemanjangan batang, pembungaan, pembuahan, serta meningkatkan jumlah buah dan besar buah (Kusumo, 1984). Giberelin dalam tumbuhan memengaruhi proses pembesaran sel (peningkatan ukuran) dan memengaruhi pembelahan sel (peningkatan jumlah). Adanya pembesaran sel mengakibatkan ukuran sel yang baru lebih besar dari sel induk. Pertambahan ukuran sel menghasilkan pertambahan ukuran jaringan, organ dan akhirnya meningkatkan ukuran organ atau bagian-bagian tanaman secara keseluruhan maupun berat atau bobot tanaman tersebut. Peningkatan pembelahan sel menghasilkan jumlah sel yang lebih banyak. Jumlah sel yang meningkat termasuk di dalam jaringan pada daun, memungkinkan terjadinya peningkatan fotosintesis penghasil karbohidrat, yang dapat memengaruhi bobot buah (Salisbury dan Ross, 1995). Giberelin mampumeningkatkan kadar auksin dalam tubuh tumbuhan dengan cara giberelin memacu sintesa enzim proteolitik yang mampu melunakkan dinding sel. Melunaknya dinding sel ini akan melepaskan amino triptofan yang merupakan prekursor auksin sehingga kadar auksin meningkat. Auksin yang mempunyai peran dalam pembelahan sel sedangkan giberelin berperan dalam pembentangan sel sehingga sinergisme diantara keduanya akan menambah ukuran sel. Untuk mempertahankan keberadaan auksin, giberelin juga berperan dalam merangsang pembentukan polihidroksi asam sinamat yaitu senyawa yang menghambat kerja dari enzim IAA oksidase dimana enzim ini merupakan enzim perusak auksin. Giberelin memicu terbentuknya enzim $\alpha$-amilase yang akan memecah amilum sehingga kadar gula dalam sel akan naik sehingga air diluar sel akan masuk kedalam sel yang akan mengakibatkan sel memanjang. Hasil dari pemecahan amilum ini juga akan digunakan untuk respirasi oleh mitokondria sehingga menghasilkan ATP yang nantinya digunakan untuk energi dalam proses pembentangan sel (Salisbury dan Ross, 1995). Proses-proses di atas akan menambah bobot buah yang dihasilkan pada suatu tanaman. Semakin besar konsentrasi yang diberikan maka akan bertambah pula ukuran suatu sel akibat adanya pembelahan dan pembentangan sehingga didapatkan buah terong dengan ukuran yang besar bila dibandingkan dengan hasil dari pemberian konsentrasi lain yang lebih kecil.

\section{Jumlah dan Berat Biji Buah Terong Jumlah Biji per Buah Terong}

Hasil penelitian perlakuan pemberian ekstrak akar eceng gondok terhadap jumlah biji per buah terong disajikan pada gambar 5.3. Hasil penelitian ini memperlihatkan bahwa pemberian ekstrak akar eceng gondok berpengaruh signifikan $(\mathrm{P}<0.05)$ terhadap jumlah biji buah terong. Jumlah biji buah terong pada tanaman yang diberi perlakuan $0 \mathrm{~g} / \mathrm{L}$ sebagai kontrol negatif $(848.2 \pm 24.9$ biji $)$ signifikan $(\mathrm{P}<0.05)$ lebih tinggi dibandingkan dengan perlakuan ekstrak akar eceng gondok $50 \mathrm{~g} / \mathrm{L}$ (762.6 $\pm 29.5 \mathrm{biji}), 100 \mathrm{~g} / \mathrm{L} \quad(665.4 \pm 29.6$ biji), $\quad 150 \mathrm{~g} / \mathrm{L} \quad(561 \pm 25.6$ biji $), \quad$ dan pemberian hormon giberelin sebagai kontrol positif $(469.4 \pm 38.8$ biji). Perlakuan ekstrak akar eceng gondok 50 $\mathrm{g} / \mathrm{L}(762.6 \pm 29.5$ biji) signifikan $(\mathrm{P}<0.05)$ lebih tinggi dibandingkan dengan perlakuan ekstrak akar eceng gondok 100 $\mathrm{g} / \mathrm{L} \quad(665.4 \pm 29.6$ biji $)$ dan perlakuan ekstrak akar eceng gondok $150 \mathrm{~g} / \mathrm{L}$ (561 \pm 25.6 biji). Perlakuan ekstrak akar eceng gondok $100 \mathrm{~g} / \mathrm{L} \quad(665.4 \pm 29.6$ biji)signifikan $(\mathrm{P}<0.05) \quad$ lebih tinggi dibandingkan dengan perlakuan ekstrak akar eceng gondok $150 \mathrm{~g} / \mathrm{L} \quad(561 \pm 25.6$ 
biji). Jumlah biji buah terong terendah eceng gondok $150 \mathrm{~g} / \mathrm{L}$. diperoleh pada perlakuan ekstrak akar

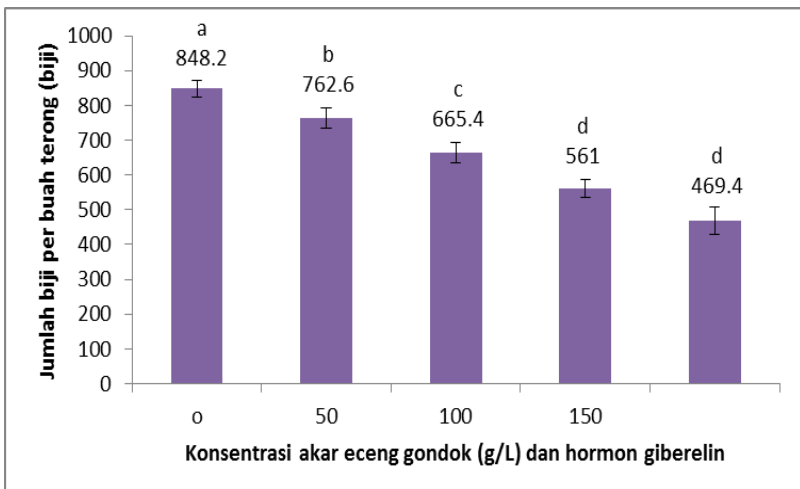

Gambar 5.3 Jumlah biji buah terong (Solanum melongena .L) setelah diberi perlakuan ekstrak akar eceng gondok dan hormon giberelin

Setiap pemberian ekstrak akar eceng gondok berpengaruh signifikan $(\mathrm{P}<0.05)$ terhadap jumlah biji buah terong (Solanum melongena .L). Pemberian ekstrak eceng gondok pada konsentrasi $150 \mathrm{~g} / \mathrm{L}$ memiliki hasil terendah, yaitu dengan rata-rata 561 biji. Perlakuan A berbeda nyata dengan perlakuan dengan konsentrasi A,B,C, dan D. Sedangkan perlakuan $\mathrm{B}$ berbeda nyata dengan perlakuan $\mathrm{C}$ dan D. Perlakuan $\mathrm{C}$ berbeda nyata dengan perlakuan D. Pada pemberian hormon giberelin (E) memiliki berat buah lebih rendah dibandingkan dengan pemberian ekstrak akar eceng gondok dengan konsentrasi D.

\section{Berat Biji per Buah Terong}

Hasil penelitian pemberian perlakuan ekstrak akar eceng gondok terhadap berat biji buah terong disajikan pada gambar 5.4. Hasil penelitian ini memperlihatkan bahwa pemberian ekstrak akar eceng gondok berpengaruh signifikan
$(\mathrm{P}<0.05)$ terhadap berat biji buah terong. berat biji buah terong pada tanaman yang diberi perlakuan $0 \mathrm{~g} / \mathrm{L}$ sebagai kontrol negatif $(8.16 \pm 0.011 \mathrm{~g})$ signifikan $(\mathrm{P}<0.05)$ lebih tinggi dibandingkan dengan perlakuan ekstrak akar eceng gondok 50 $\mathrm{g} / \mathrm{L}(7.7 \pm 0.015 \mathrm{~g}), 100 \mathrm{~g} / \mathrm{L}(7.02 \pm 0.024$ $\mathrm{g}), 150 \mathrm{~g} / \mathrm{L}(6.14 \pm 0.2 \mathrm{~g})$, dan pemberian hormon giberelin sebagai kontrol positif $(5.42 \pm 0.69 \mathrm{~g})$. Perlakuan ekstrak akar eceng gondok $50 \mathrm{~g} / \mathrm{L} \quad(7.7 \pm 0.015$ g)signifikan $\quad(\mathrm{P}<0.05) \quad$ lebih tinggi dibandingkan dengan perlakuan ekstrak akar eceng gondok $100 \mathrm{~g} / \mathrm{L}(7.02 \pm 0.024$ g) dan perlakuan ekstrak akar eceng gondok $150 \mathrm{~g} / \mathrm{L}(6.14 \pm 0.2 \mathrm{~g})$. Perlakuan ekstrak akar eceng gondok $100 \mathrm{~g} / \mathrm{L}$ $(7.02 \pm 0.024 \mathrm{~g})$ signifikan $(\mathrm{P}<0.05)$ lebih tinggi dibandingkan dengan perlakuan ekstrak akar eceng gondok $150 \mathrm{~g} / \mathrm{L}$ $(6.14 \pm 0.2 \mathrm{~g})$. Jumah biji buah terong terendah diperoleh pada perlakuan ekstrak akar eceng gondok $150 \mathrm{~g} / \mathrm{L}$. 


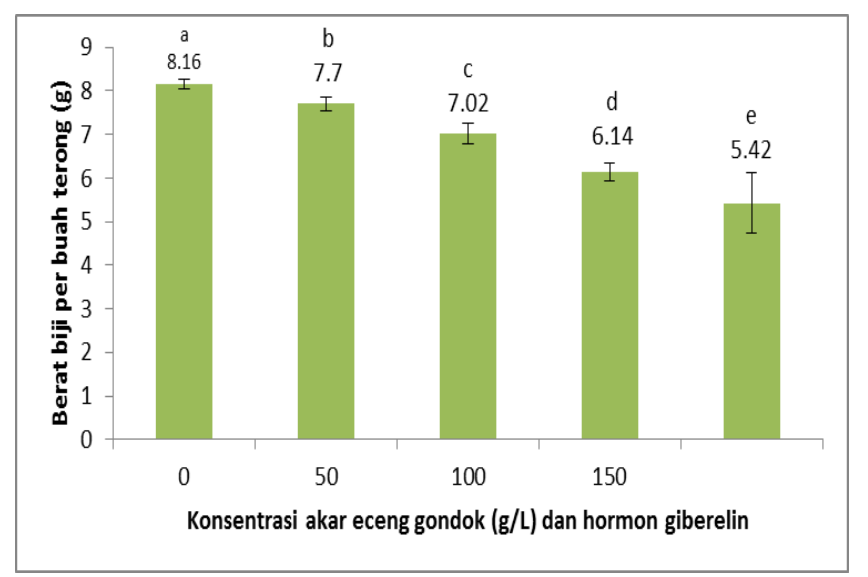

Gambar 5.4 Berat biji buah terong (Solanum melongena .L) setelah diberi perlakuan dengan ekstrak akar eceng gondok dan hormon giberelin

Setiap pemberian ekstrak akar eceng gondok berpengaruh signifikan $(\mathrm{P}<0.05)$ terhadap berat biji buah terong (Solanum melongena .L). Pemberian ekstrak eceng gondok pada konsentrasi $150 \mathrm{~g} / \mathrm{L}$ memiliki hasil terendah, yaitu dengan rata-rata $6.14 \mathrm{~g}$. Perlakuan A berbeda nyata dengan perlakuan A,B,C, dan D. Sedangkan perlakuan B berbeda nyata dengan perlakuan $\mathrm{C}$ dan $\mathrm{D}$. Perlakuan $\mathrm{C}$ berbeda nyata dengan perlakuan D. Pada pemberian hormon giberelin (E) memiliki berat buah lebih rendah dibandingkan dengan pemberian ekstrak akar eceng gondok dengan konsentrasi D.

Hormon endogen termasuk hormon giberelin yang disintesis pada jaringan merismatik antara lain daun, primordium cabang, akar dan biji juga sering digunakan sebagai zat pengatur tumbuh (Permatasari, et al., 2016).

Giberelin (GA3) merupakan kelompok fitohormon yang berperan penting dalam mengkoordinasikan pertumbuhan buah dan pengembangan benih (Pandofilni, 2009). Pada tahap awal pembuahan, sel inti generatif 1 yang membuahi sel ovule menghasilkan zigot, sedangkan sel inti generatif 2 yang melebur bersama sel inti kandung lembaga sekunder menghasilkan endosperm. Aktivitas sintesis fitohormon yang terdapat pada giberelin dan auksin berpengaruh terhadap metabolisme pada sel-sel yang mengalami pembuahan, terutama pada sel-sel zigot (Gillaspy, et al., 1993). Hormon giberelin akan mencegah sampainya buluh serbuk sari ke celah mikropil pada ovarium dengan merusak dan menghambat perkembangan buluh serbuk sari. Akibatnya, sel sperma tidak dapat bertemu dengan sel telur dan zigot tidak terbentuk. Jika zigot tidak terbentuk, maka perkembangan bakal biji terhenti dan tidak berbentuk biji. Partenokarpi dikatakan terjadi, apabila buah terbentuk tanpa diawali proses fertilisasi. Jadi pemberian hormon giberelin mampu menginduksi terbentuknya buah secara partenokarpi (Pardal, 2011). Penghambatan pembentukan biji dengan partenokarpi pada buah biasanya dilakukan dengan cara mengaplikasi zat pengatur tumbuh, seperti giberelin pada bunga tanaman (Purnamaningsih, et al., 2010).

Terbentuknya biji pada buah terong dapat dicegah dengan menggunakan hormon giberelin dengan cara menghambat proses fertilisasi, sedangkan disini ekstrak akar eceng gondok sebagai pengganti hormon giberelin. Menurut Permatasari, et al., 
(2016), pembentukan biji buah dapat dicegah dengan menggunakan hormon giberelin dengan cara menghambat proses fertilisasi, hormon giberelin dapat mencegah buluh serbuk sari sampai ke mikropil dan mengakibatkan sel telur tidak bertemu dengan sel sperma sehingga tidak dihasilkan embrio. Perkembangan bakal biji akan terhenti apabila pebentukan embrio tidak terjadi sehingga tidak akan terbentuk biji. Partenokarpi dikatakan berhasil apabila pembentukan buah tidak didahului dengan proses fertilisasi, dengan kata lain peran giberelin pada peristiwa partenokarpi adalah menggantikan proses fertilisasi (Permatasari, et al., 2016).Zulkarnain (2009) mengemukakan bahwa dimana kadar $\mathrm{GA}_{3}$ meningkat dan mencapai maksimum lebih awal, tetapi menurun dengan tajam saat biji berhenti tumbuh dan memasuki periode pematangan. Jadi dengan pemberian $\mathrm{GA}_{3}$ maka dapat membantu proses pematangan dan pertumbuhan endosperm maupun embrio, dimana biji sebagai pensuplai ZPT bagi pertumbuhan dan perkembangan bakal buah namun karena telah dilakukan penambahan $\mathrm{GA}_{3}$ dari luar maka perkembangan buah tetap terjadi tetapi terjadi penghambatan pertumbuhan embrio sehingga biji tidak terbentuk (Teguh, 2012).Penggunaan giberelin banyak dilakukan oleh produsen anggur tanpa biji (Suwanto, 2002). Perlakuan giberelin ini mengakibatkan tidak terbentuknya biji karena gangguan pertumbuhan tabung sari sebelum pembuahan (Suwanto, 2002). Aplikasi hormon giberelin tebukti berpengaruh terhadap pembentukan buah tanpa biji pada semangka (Annisah, 2009).
Giberelin memacu pertumbuhan biji dorman dan pertumbuhan kuncup dorman, berperan dalam pembungaan, pengangkutan makanan dan pengangkutan unsur mineral dalam sel penyimpanan pada biji, efek lain dari giberelin yaitu menyebabkan perkembangan buah paertenokarpi (tanpa biji) pada beberapa spesies, menunjukkan fungsi normalnya dalam pertumbuhan buah (Heddy, 1986).

\section{Tebal Kulit per Buah Terong}

Hasil penelitian pemberian perlakuan ekstrak akar eceng gondok terhadap tebal kulit buah terong disajikan pada gambar 5.5. Hasil penelitian ini memperlihatkan bahwa pemberian ekstrak akar eceng gondok berpengaruh signifikan $(\mathrm{P}<0.05)$ terhadap tebal kulit buah terong. Tebal kulit buah terong pada tanaman yang diberi perlakuan $0 \mathrm{~g} / \mathrm{L}$ sebagai kontrol negatif $(1.64 \pm 0.011 \mathrm{~mm})$ signifikan $\quad(\mathrm{P}<0.05) \quad$ lebih tinggi dibandingkan dengan perlakuan ekstrak akar eceng gondok $50 \mathrm{~g} / \mathrm{L}(0.36 \pm 0,011$ $\mathrm{mm}), 100 \mathrm{~g} / \mathrm{L}(1.06 \pm 0.011 \mathrm{~mm}), 150 \mathrm{~g} / \mathrm{L}$ $(0.78 \pm 0.08 \mathrm{~mm})$, dan pemberian hormon giberelin sebagai kontrol positif $(0.56 \pm 0.05 \mathrm{~mm})$. Perlakuan ekstrak akar eceng gondok $50 \quad \mathrm{~g} / \mathrm{L} \quad(0.36 \pm 0.011$ $\mathrm{mm})$ signifikan $\quad(\mathrm{P}<0.05)$ lebih tinggi dibandingkan dengan perlakuan ekstrak akar eceng gondok $100 \mathrm{~g} / \mathrm{L}(1.06 \pm 0.011$ $\mathrm{mm})$ dan perlakuan ekstrak akar eceng gondok $150 \mathrm{~g} / \mathrm{L} \quad(0.78 \pm 0.08 \mathrm{~mm})$. Perlakuan ekstrak akar eceng gondok 100 $\mathrm{g} / \mathrm{L}(1.06 \pm 0.011 \mathrm{~mm})$ signifikan $(\mathrm{P}<0.05)$ lebih tinggi dibandingkan dengan perlakuan ekstrak akar eceng gondok 150 $\mathrm{g} / \mathrm{L}(0.78 \pm 0.08 \mathrm{~mm})$. Tebal kulit buah terong terendah diperoleh pada perlakuan ekstrak akar eceng gondok $150 \mathrm{~g} / \mathrm{L}$. 


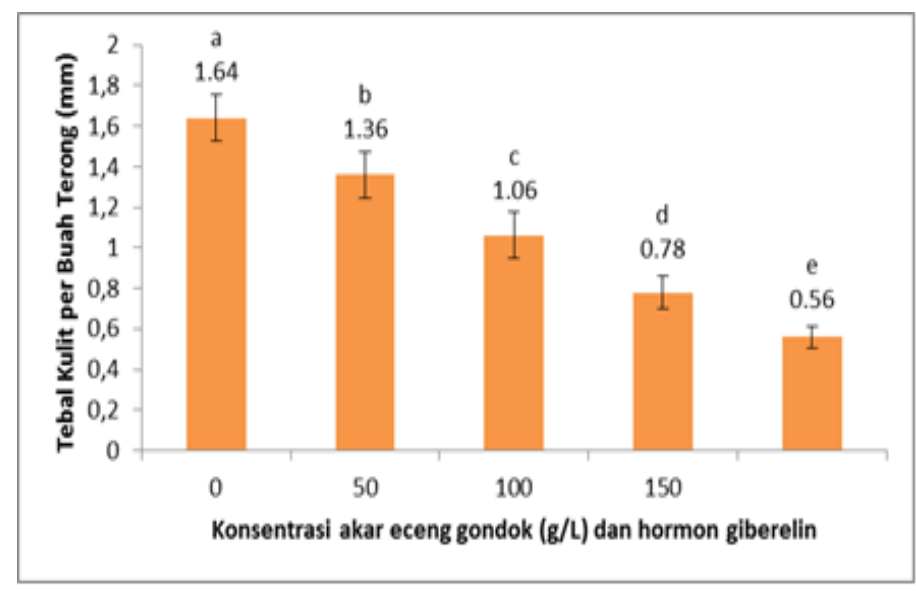

Gambar 5.4 Tebal kulit buah terong (Solanum melongena .L) setelah disemprot dengan ekstrak akar eceng gondok dan hormon giberelin

Setiap pemberian ekstrak akar eceng gondok berpengaruh signifikan $(\mathrm{P}<0.05)$ terhadap tebal kulit buah terong (Solanum melongena .L). Pemberian ekstrak eceng gondok pada konsentrasi $150 \mathrm{~g} / \mathrm{L}$ memiliki hasil terendah, yaitu dengan rata-rata $0.78 \mathrm{~mm}$. Perlakuan A berbeda nyata dengan perlakuan dengan konsentrasi A,B,C, dan D. Sedangkan perlakuan $\mathrm{B}$ berbeda nyata dengan perlakuan $\mathrm{C}$ dan D. Perlakuan C berbeda nyata dengan perlakuan D. Pada pemberian hormon giberelin $(\mathrm{E})$ memiliki berat buah lebih rendah dibandingkan dengan pemberian ekstrak akar eceng gondok dengan konsentrasi D.

Dari hasil penelitian ini menunjukkan bahwa pemberian ekstrak akar eceng gondok sebagai pengganti hormon giberelin dapat mempengaruhi ketebalan pada kulit buah terong. Pada konsentrasi $150 \mathrm{~g} / \mathrm{L}$ berpengaruh nyata terhadaptebal kulit buah terong. Farlex (2004), mengemukakan bahwa asam giberelat (GA) khususnya GA3 berperan dalam proses pembungaan dan dapat mempengaruhi tebal tipisnya kulit buah semangka.

$$
\text { Upaya menghasilkan buah }
$$
partenokarpi dapat ditempuh melalui beberapa cara, diantaranya dengan menyemprotkan ekstrak akar eceng gondok pada tandan bunga tanaman. Hasil penelitian ini menunjukkan bahwa penyemprotan ekstrak akar eceng gondok mampu mempengaruhi pembentukan buah terong yang terbentuk secara partenokarpi, sebagaimana pada penelitian Windarti dan Sopandi (2018), yang dikemukakan bahwa pemberian ekstrak akar eceng gondok berpengaruh signifikan terhadap jumlah biji, berat buah, jumlah hasil panen, dan tinggi tanaman. Pada konsentrasi $75 \mathrm{~g} / \mathrm{L}$ memiliki hasil terbaik dibandingkan dengan konsentrasi $50 \mathrm{~g} / \mathrm{L}$ dan $25 \mathrm{~g} / \mathrm{L}$.

\section{Kesimpulan}

Berdasarkan analisis data, maka dapat disimpulkan bahwa:

1. Pemberian ekstrak akar eceng gondok (Eichhornia crassipes)berpengaruh signifikan $\quad(\mathrm{p}<0.05) \quad$ terhadap karakteristik buah dan biji terong (Solanum melongena .L var. kenari).

2. Pemberian ekstrak akar eceng gondok (Eichhornia crassipes)belum dapat menggantikan hormon giberelin sintetis terhadap karakteristik buah 
dan biji terong (Solanum melongena .L var. kenari).

\section{Saran}

Penelitian lebih lanjut untuk optimalisasi konsentrasi ekstrak akar eceng gondok (Eichhornia crassipes) perlu diteliti lebih lanjut sehingga dapat menggantikan hormon giberelin sintetis.

\section{DAFTAR PUSTAKA}

Annisah. 2009. Pengaruh Induksi Giberelin Terhadap Pembentukan Buah Partenokarpi Pada Beberapa Varietas Tanaman Semangka (Citrullus Vulgaris Schard). Skripsi. Fakultas Pertanian. Universitas Sumatra Utara. Medan.

Anonim. 2011. Memahami Berbagai Macam penyakit. Dialihbahasakan oleh Paramita. Jakarta: PT Indeks.

Badan Pusat Statistik Republik Indonesia. (2017). Luas Panen, Produksi dan Produktivitas Terong, 2013-2014. Diambil dari www.bps.go.id. [29 November 2018]

Bayyinatul, M., R. Susilowati, dan A. Kusumastuti. 2012. Pemanfaatan Tepung Hasil Fermentasi Eceng Gondok (Eichornia crassipes) sebagai Campuran Pakan Ikan untuk Meningkatan Berat Badan dan Daya Cerna Protein Ikan Nila Merah (Oreochromis sp). Jurnal. Universitas Islam Negeri. Malang.

Chudasama, RS dan Thaker, VS 2007. Hubungan antara asam giberelat dan parameter pertumbuhan dalam mengembangkan biji dan pod kacang merpati. Brazil Jurnal Fisiologi Tumbuhan.

Gillaspy, G., Ben-David, H., and Gruissem, W. (1993). Fruits: A developmental perspective. Plant Cell 5: 1439-1451.

Heddy, S. 1986. Hormon Tumbuhan. Rajawali, Jakarta. 97 pp.

Jumini dan A. Marliah. 2009. Pertumbuhan dan hasil tanaman terung akibat pemberian pupuk daun gandasil D dan zat pengatur tumbuh harmonik. Jurnal Floratek,4:73-80.

Kusumo. 1984. Zat Pengatur Tumbuh. Jakarta: CV. Yasaguna.

Musbakri, 1999. Ekstraksi dan Identifikasi Giberelin Dari Akar Eceng Gondok (Eichhornia crassipes). Skripsi. Fakultas Teknologi Pertanian. Institut Pertanian Bogor.

Natesh, N., B.,S. Vyakarnahal., M.S. Gouda dan V.K. Deshpande. 2005. Influence of Growth Regulators on Growth, Seed Yield and Quality of Chili cv. Byadgi Kaddi. Karnataka J. Agric. Sci. 18 (1) : 36-38.

Pandolfini, T., 2009. Seedless Fruit Production by Hormonal Regulation of Fruit Set. Nutrients, 1(2): 168177.

Pardal, S.J., 2001. Pembentukan Buah Partenokarpi melalui Rekayasa Genetik. Dikut ip dari: http://biogen.litbang.deptan.go.id/ter bitan/pdf/agrobio_4_2_45-49.pdf. Diakses tanggal 11 Juli 2019

Permatasari, 2016. Pengaruh Pemberian Hormon Giberelin Terhadap Pertumbuhan Buah Secara Partenokarpi pada Tanaman Tomat Varietas Tombatu F1. LenteraBio Vol. 5 No.1: 25-31.

Purnamaningsih. 2010. Perakitan Transgenik Mangga Varietas Gedong Gincu dan Transgenik Duku Varietas Kupeh Bersifat Seedless dengan Efisiensi Regenerasi $50 \%$ dan Transformasi 40 \%. J. Hort. 19(2). Hal 125-130.

Purnamaningsih. R., Kosmiatin, M. dan Apriana, A. 2010. Perakitan Transgenik Mangga Varietas Gedong Gincu dan Transgenik Duku Varietas Kupeh Bersifat Seedless Dengan Efisiensi Regenerasi $50 \%$ dan Transformasi 40\%. Laporan Akhir Program Riset Insentif (RIPP). Badan Penelitian dan Pengembangan Pertanian. Balai 
Besar Penelitian dan Pengembangan

Bioteknologi dan Sumberdaya

Genetik Pertanian. Kampus

Penelitian Pertanian Cimanggu.

Salisbury, FB, Ross, C.W, 1995. Fisiologi

Tumbuhan Jilid 3. Penerjemah

Lukman, Sumaryono. Penerbit ITB

Press. Bandung.

Windarti Ferdia dan Tatang Sopandi. 2018.Reduksi Jumlah Biji Cabai

Rawit (Capsicum Frutescents)

Dengan Menggunakan Sari Akar

Eceng Gondok (Eichhornia

Crassipes). Skripsi. Fakultas

Matematika dan Ilmu Pengetahuan

Alam. Universitas PGRI Adi Buana

Surabaya. Surabaya.

Suwanto, A., 2002. Berbahayakah

Semangka dan Anggur Tanpa Biji.
Wordpress, 2009. Hormon

Tumbuh/ZPT. Dikutip dari: http://hijauqoe.wordpress.com/2009/ 01/03/hormonik-hormon-tumbuhzpt/ Diakses tanggal 10 Juli 2019.

Wardini. 2008. Analisi Kandungan Nutrisi Pada Eceng Gondok (Eichornia Crassipes) Sebagai Bahan Pakan Ternak.

http://Digilib.Itb.Ac.Id/Gdl.Php?Mo $\mathrm{d}=$ Browser $\& O p=$ JbptitbppGdlcourse2001-R-631-Sme. Diakses Pada Tanggal 29 November 2018

Wareing, P.F. dan I.D.J. Phillips. 2001. The Control of Growth and Differentiation in Plants. Pergamon Press. New York. 